\title{
Radio-adaptive response and correlation of non-homologous end joining repair gene polymorphisms [XRRC5 (3R/2R/1R/0R), XRCC6(C/G) and XRCC7 (G/T)] in human peripheral blood mononuclear cells exposed to gamma radiation
}

Shridevi Shelke ${ }^{1}$ and Birajalaxmi Das ${ }^{1,2^{*}}$

\begin{abstract}
Background: Radio-adaptive response (RAR) is transient phenomena, where cells conditioned with a small dose (priming) of ionizing radiation shows significantly reduced DNA damage with a subsequent high challenging dose. The role of DNA double strand break repair gene polymorphism in RAR is not known. In the present study attempt was made to find out the influence of NHEJ repair gene polymorphisms [a VNTR; XRCC5 (3R/2R/1R/OR); two single nucleotide polymorphisms (SNPs); XRCC6 (C/G) and XRCC7 (G/T)] with DNA damage, repair and mRNA expression in human PBMCs in dose and adaptive response studies. Genomic DNA extracted from venous blood samples of 20 random healthy donors (16 adaptive and 4 non-adaptive) and genotyping of NHEJ repair genes was carried out using PCR amplified length polymorphism.

Results: The dose response study revealed significant positive correlation of genotypes at XRRC5 (3R/2R/1R/OR), $X R C C 6(C / G)$ and XRCC7 (G/T) with DNA damage. Donors having genotypes with $2 R$ allele at XRCC5 showed significant positive correlation with mRNA expression level (OR/2R: $r=0.846, P=0.034 ; 1 \mathrm{R} / 2 \mathrm{R}: r=0.698, P=0.0001$ and 2R/2R: $r=0.831, P=0.0001$ ) for dose response. Genotypes $C / C$ and $C / G$ of XRCC6 showed a significant positive correlation $(P=0.0001)$, whereas, genotype $T / T$ of $X R C C 7$ showed significant negative correlation $(r=-0.376, P=$ 0.041) with mRNA expression.

Conclusion: Interestingly, adaptive donors having $C / G$ genotype of XRCC6 showed significantly higher $(P<0.05)$ mRNA expression level in primed cells suggesting their role in RAR. In addition, NHEJ repair gene polymorphisms play crucial role with radio-sensitivity and RAR in human PBMCs.
\end{abstract}

Keywords: Radio-adaptive response, DNA double strand breaks, Non-homologous end joining (NHEJ) repair gene polymorphism, Genotypes

\footnotetext{
* Correspondence: biraj@barc.gov.in; birajalaxmi@yahoo.co.in

'Low Level Radiation Research Section, Radiation Biology \& Health Sciences Division, Bio-Sciences Group, Bhabha Atomic Research Centre, Trombay, Mumbai 400 085, India

${ }^{2}$ Homi Bhabha National Institute (HBNI), Anushaktinagar, Mumbai 400094, India
}

C C The Author(s). 2021 Open Access This article is licensed under a Creative Commons Attribution 4.0 International License, which permits use, sharing, adaptation, distribution and reproduction in any medium or format, as long as you give appropriate credit to the original author(s) and the source, provide a link to the Creative Commons licence, and indicate if changes were made. The images or other third party material in this article are included in the article's Creative Commons licence, unless indicated otherwise in a credit line to the material. If material is not included in the article's Creative Commons licence and your intended use is not permitted by statutory regulation or exceeds the permitted use, you will need to obtain permission directly from the copyright holder. To view a copy of this licence, visit http://creativecommons.org/licenses/by/4.0/. The Creative Commons Public Domain Dedication waiver (http://creativecommons.org/publicdomain/zero/1.0/) applies to the data made available in this article, unless otherwise stated in a credit line to the data. 


\section{Introduction}

Environmental exposures such as chemical and physical mutagens including ionizing radiation may (IR) pose concern to human health. However, it is important to understand the underlying biological mechanisms regarding the individual susceptibility to radiation exposure. IR induces a variety of DNA damages/lesions such as single strand breaks (SSBs), double strand breaks (DSB) and base damages in human cells in addition to the basal endogenous DNA damages produced by oxidative stress. Radiation induced SSBs and oxidative DNA damages produced in a cell are large in number per 1.0 Gy of low Linear energy transfer (LET) IR, as compared to DNA DSBs, which are very few in number [1]. However, DSBs are most lethal to the cells leading either cell death or may cause adverse consequences leading to genomic instability and carcinogenesis, if not repaired or mis-repaired. Very often, mis-repaired or defective cells accumulate lethal mutations, rearrangement of complex chromosomal aberrations or chromothripsis [2, 3]. These changes activate DNA damage response (DDR), cell cycle check points, and cell survival pathways along with molecular pathways of DNA repair. Radio-adaptive response (RAR) occurs in cells/tissues, when an exposure of low dose (priming dose) of IR helps in reducing the damage caused by a single high dose (challenging dose) of IR [4]. RAR is observed in human cells with a priming dose of IR between (0.001-0.5 Gy) and the challenging dose between $(0.1-5.0 \mathrm{~Gy})$ with incubation time between $(2-24 h)$ [3]. There are reports which demonstrate that circulating lymphocytes of individuals show differential response to a high challenging dose. There are two groups of donors i.e., adaptive and non-adaptive, depending upon radio-sensitivity or radio-resistance of individuals. However, it is important to understand the underlying mechanism regarding the genetic basis of this variation in response to IR. Recently, association of base excision repair (BER) gene polymorphisms in RAR has been reported in human peripheral blood mononuclear cells exposed to gamma radiation [5].

Non homologous end joining (NHEJ) pathway of DSB repair is one of the major repair pathways of choice in circulating lymphocytes which is in $G_{0} / G_{1}$ phase of the cell cycle [6]. DNA polymorphism such as studies on single nucleotide polymorphisms (SNPs) and variable number of tandem repeats (VNTRs) at NHEJ repair genes (XRCC5, XRCC6 and XRCC7) are associated with an increased risk of radiation sensitivity and cancer [7]. Deficiency in DNA repair increases radio-sensitivity in many cancers and human diseases [8]. DNA repair deficient syndromes such as xeroderma pigmentosum (XP), cockayne syndrome (CS), fanconi anemia (FA) and nijmegen breakage syndrome (NBS) are very often show radio-sensitivity. Hence, studying association of genetic variants such as SNPs and VNTRs of DNA repair genes may contribute to the susceptibility to a particular disease or radiation sensitivity [9]. There are studies which suggest that SNPs from DSB repair pathway genes may modulate gamma-radiation induced mutagen sensitivity [10]. Recently, we have also reported that IR influences DNA repair gene polymorphisms and individual radiosensitivity $[5,11]$.

The presence of polymorphic alleles in DNA repair genes may alter the repair capacity of a particular individual thus affecting individual susceptibility in developing cancer [12]. It has also been reported that individuals showing severely compromised repair capacity have increased mutation rates, genomic instability, and an increased risk of cancer [13]. Healthy individuals differ in their intrinsic capacity to repair [14], which could be due to alterations in gene expression and association with DNA repair gene polymorphisms.

Low-dose ionizing radiation (LDIR) exposure below 100 mGy (0.1 Gy) may induce RAR and protects the cells from DNA damage, repair and cell killing. However, DNA DSBs are repaired through DSB repair pathways in order to keep the cells maintain genomic integrity [15]. Both homologous recombination repair (HRR) or nonhomologous end-joining (NHEJ) repair mechanisms are activated due to LDIR exposure in cell lines in culture, but NHEJ is more active in resting PBMCs. Recent studies from high level natural background radiation areas have shown efficient repair of DSBs and activation of DDR, NHEJ, HR and other signaling pathways in PBMCs at low lose radiation exposed human population $[16,17]$. Evidences of the involvement DDR and BER repair pathway in human PBMCs have also been found at DNA damage, repair and mRNA expression level [18-20]. Our earlier studies showed variability in radioadaptive response in NHEJ repair pathway among the healthy donors [21].

In the present study, attempt was made to study genetic polymorphism of XRCC5 (3R/2R/1R/0R), XRCC6 $(\mathrm{C} / \mathrm{G})$ and $X R C C 7(\mathrm{G} / \mathrm{T})$ from NHEJ repair pathway and their possible association with DNA damage and mRNA expression profile among healthy donors. The role of different genotypes in RAR is also explored. Schematic representation of the gene mapping for these polymorphisms are given in Fig. 1. The characteristics of these genes are as follows:

XRCC5 (KU80)-3R/2R/1R/0R is a novel VNTR located in the promoter region of XRCC5 gene [22, 23]. It displays four different alleles with repetitive sequences of 21 nucleotides repeats (3R, 2R, 1R and 0R). For instance, $3 R$ refers to three 21 nucleotides repeats (3R) ( -221 to -160 relative to the initiation of Transcription), $2 \mathrm{R}$ refers to two 21 nucleotides repeats (2R) $(-201$ to -160$)$, $1 \mathrm{R}$ refers to one 21 nucleotides repeat (1R) $(-180$ to - 


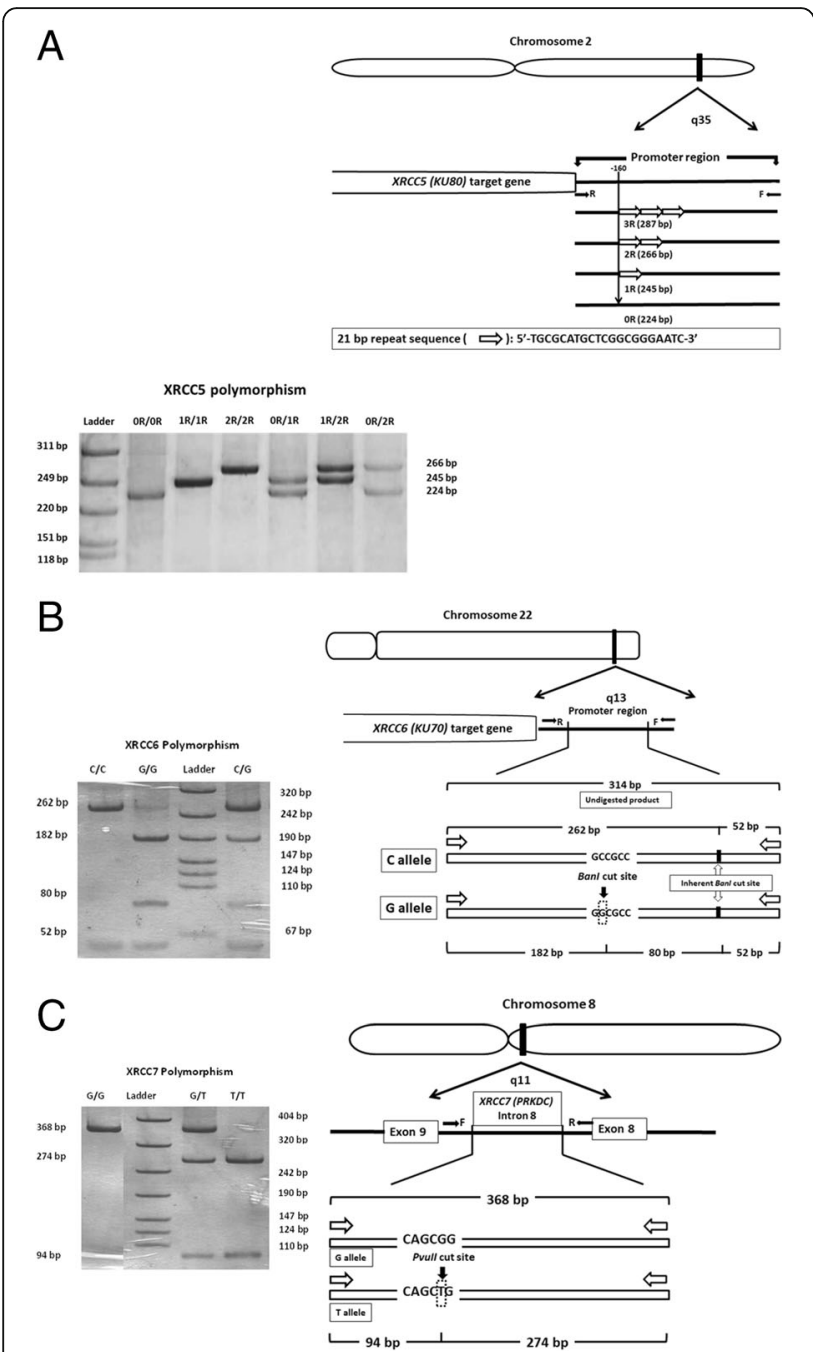

Fig. 1 Gene mapping and Silver stained PAGE (6\%). a XRCC5 (KU80) - 3R/2R/1R/OR VNTR polymorphism. b XRCC6 (KU70) - 61C/G. c XRCC7 (PRKDC) - G/T6721G/T. Ladder in Fig. a \& c: $\phi X 174$ Hinfl digest (Banglore Genei India Pvt. Ltd.); ladder used in Fig. b: DNA molecular weight marker VIII (Roche diagnostic Gmbh, Germany)

160), and a zero repeat (0R). This polymorphism is found to be associated with acute myeloid leukemia (AML), chronic myeloid leukemia (CML) [23-25]. XRCC6 (KU70)-61C/G polymorphism is located in the promoter region of chromosome 22. It is also known to be associated with increased risk of breast cancer [26] and AML [23]. Genetic variants of XRCC7 (PRKDC)6721G/T is located in the intron 8 of chromosome 8 and has shown to elevate the risk of glioma and renal cell carcinoma [27, 28].

DNA repair polymorphisms are influenced by several susceptibility factors including environmental exposures, which can affect genome integrity and thus can be used as biomarkers of cancer risk in human population [29]. Genetic polymorphisms may affect genotype-phenotype correlation, but not yet established for most of the polymorphisms [30]. Hence, in recent years, efforts are made to develop possible biomarkers of DNA repair gene polymorphisms for efficient detection, treatment, and prevention of human diseases including cancer [31].

The objective of the present study was to find out the correlation of genotypes observed at three NHEJ repair gene polymorphisms $[X R C C 5(3 \mathrm{R} / 2 \mathrm{R} / 1 \mathrm{R} / 0 \mathrm{R})$, XRCC6 $(\mathrm{C} / \mathrm{G})$ and $X R C C 7(\mathrm{G} / \mathrm{T})$ ] with respect DNA damage, DNA repair capacity (DRC) and mRNA expression and their influence in RAR.

\section{Materials and methods \\ Ethic statement}

Venous blood samples were collected from 20 random, normal and healthy donors (males, Age: 25 to 40 years, non-smokers) in EDTA containing vials with written informed consent, which was approved by Medical ethics committee, Trombay, BARC, Mumbai.

\section{Collection of blood samples, separation of PBMCs, irradiation and sample preparation}

In the present study, approximately $12 \mathrm{ml}$ blood from each donor was collected, PBMCs were separated through gradient centrifugation by overlaying whole blood on Histopaque-1077 (Sigma Aldrich, USA) solution, centrifugation at $400 \mathrm{X} \mathrm{g}$ for $30 \mathrm{~min}$ at room temperature. The layer containing PBMC was removed and washed twice with phosphate-buffered saline and used for DNA damage and mRNA expression studies. Dose response, time point kinetics and RAR studies were conducted using DNA damage, repair and mRNA expression profile.

For dose response study, PBMCs were irradiated at various doses i.e., 0.1, 0.3, 0.6, 1.0 and 2.0 Gy of gamma radiation using ${ }^{60} \mathrm{Co} \gamma$-radiation source (Bhabhatron II, Panacea Medical Technologies, Bangalore, India) at a dose rate of $1.0 \mathrm{~Gy} / \mathrm{min}$. Post irradiation time point kinetics study for quantitation of DSBs and time dependent changes of mRNA expression profile were determined at $2.0 \mathrm{~Gy}$ in PBMCs at different time points $(30 \mathrm{~min}, 60$ $\mathrm{min}, 120 \mathrm{~min}$ and $240 \mathrm{~min}$ ) along with un-irradiated control. For all the experiments, un-irradiated PBMCs were simultaneously processed as a control along with the irradiated samples. Radio-adaptive response study was carried out where PBMCs were exposed in vitro with a priming dose of $0.1 \mathrm{~Gy}$ followed by $2.0 \mathrm{~Gy}$ of gamma radiation after $4 \mathrm{~h}$ incubation and analysed for DNA damage, post irradiation time point kinetics and mRNA expression profile. Aliquots of PBMCs $\left(\sim 10^{6}\right.$ cells $/ \mathrm{ml}$ ) were prepared in duplicates for each dose and time point to quantitate DNA damage, repair kinetics and mRNA expression profile. 
Measurement of DNA DSBs by neutral comet assay

Neutral single cell gel electrophoresis was carried out for quantitation of DNA DSB, post-irradiation changes and RAR study as described elsewhere [21]. About 100 cells (50 cells from each slide) were randomly selected and quantified using TriTek Comet Score TM Version 1.5. The percentage of DNA in the tail was calculated as per the calculation as follows:

$$
\% \text { DNA in Tail }=\left[\frac{\text { Total Tail Intensity }}{\text { Total comet Intensity }}\right] \times 100
$$

\section{Analysis of $m R N A$ expression by real time $q-P C R$}

Total RNA was extracted and cDNA was prepared from irradiated as well as sham irradiated control PBMCs. Analysis of mRNA expression pattern of the NHEJ repair genes [XRCC5 (KU80), XRCC6 (KU70) and XRCC7 $(P R K D C)]$ was carried out using SYBR green based real time $\mathrm{q}-\mathrm{PCR}$ for dose response, post irradiation time point kinetics and RAR studies. Details of the primer sequences and PCR cycling conditions were as described elsewhere [21]. The results are expressed in normalized ratio as described by Pfaffle et al. (2001) [32] and the calculation is as follows:

Normalized ratio $=\frac{(\text { Concentration of Target/Concentration of reference })_{\text {sample }}}{(\text { Concentration of Target/Concentration of reference })_{\text {Calibrator }}}$

\section{Genetic polymorphism study}

Approximately $2 \mathrm{ml}$ of venous blood samples were collected in EDTA containing vaccutainers from each donor. Genomic DNA was extracted from whole blood using non-enzymatic salt precipitation method [33]. DNA was quantified by taking absorbance at $260 \mathrm{~nm}$ and $280 \mathrm{~nm}$ using Picodrop Microlitre Spectrophotometer (Pico100, Picodrop Ltd., UK). The ratio of absorbance at 260 and $280 \mathrm{~nm}$ was determined to check for the purity of DNA.

\section{PCR amplified fragment length polymorphism}

Genetic polymorphisms were studied at selected SNPs for XRCC6 (C/G), XRCC7 (G/T) and a VNTR at XRCC5 $(3 \mathrm{R} / 2 \mathrm{R} / 1 \mathrm{R} / 0 \mathrm{R})$. The SNPs of XRCC6 (C/G), and XRCC7 $(\mathrm{G} / \mathrm{T})$ polymorphism were analyzed by PCR amplified restriction fragment length polymorphism (PCR-RFLP). The VNTR at XRCC5 (3R/2R/1R/0R) polymorphism was studied by PCR amplified fragment length polymorphism (Amp-FLP). All the PCR reactions were performed on Master cycler gradient thermocycler (Eppendorf, Hamburg, Germany) in a final volume of $25 \mu$ l containing locus specific primers (5 picomoles of each primer), $50 \mathrm{ng}$ genomic DNA, $1.5 \mathrm{mM} \mathrm{MgCl}_{2}, 200 \mu$ moles each dNTPs and 0.5 unit of Taq DNA Polymerase. Primer sequences and PCR conditions used for polymorphism study are given in Table 1 and Table 2 respectively.

\section{Restriction digestion of PCR amplified products}

Approximately $8 \mu \mathrm{l}$ of amplicons were digested overnight with BanI and PvulI restriction endonucleases (New England Biolabs Inc., UK) at $37^{\circ} \mathrm{C}$ for XRCC6(C/G) and $X R C C 7(\mathrm{G} / \mathrm{T})$ polymorphisms, respectively. Undigested and restriction enzyme (RE) digested PCR product sizes for XRCC5 (0R/1R/2R/3R), XRCC6 (C/G) and XRCC7 $(\mathrm{G} / \mathrm{T})$ polymorphisms are given in Table 3 . The $\mathrm{RE}$ digested PCR products were resolved on $10 \%$ nondenaturing polyacrylamide gels (PAGE) followed by silver staining (Perkin Elmer method). Silver stained gels with different allele sizes (bps) for each polymorphism (XRCC5, XRCC6 and XRCC7) are given in Fig. 1.

\section{Statistical analysis}

Linear regression analysis was performed to study dose response at DNA damage. For mRNA expression analysis, the normalized ratio was calculated as described by Pfaffle (2001) [32]. Pearson's correlation coefficient was calculated to determine the correlation between various genotypes with DNA damage and mRNA expression profile. All the statistical analysis was performed using SPSS software (version 17.0). For all the experiments, $P \leq 0.05$ was set for significance level.

\section{Results}

DNA polymorphism study of XRCC5 (KU80), XRCC6 (KU7O) and XRCC7 (PRKDC) genes were carried out among 20 donors and the genotypes were correlated with the DNA damage, repair and transcriptional profile. Linear regression was carried out for dose response study at DNA damage and gene expression level at each of the genotypes to find out the association of polymorphisms at these above genes with DNA damage, mRNA expression and inter-individual variation if any. RAR study was also carried out in primed and non-primed cells of 16 adaptive and 4 non-adaptive donors, where genotypes observed at NHEJ polymorphisms were correlated with biological end points such as DNA damage, repair and mRNA expression.

Table 1 Locus specific primer sequences of XRCC5, XRCC6 and $X R C C 7$ genes used for polymorphism study

\begin{tabular}{lll}
\hline Name of the primer & Primer sequence & bp \\
\hline XRCC5(KU80) PR-1 (forward) & 5'-AGGCGGCTCAAACACCACAC-3' & 20 \\
XRCC5(KU80) PR-2 (reverse) & 5'-CAAGCGGCAGATAGCGGAAAG-3' & 21 \\
XRCC6 (KU70) PR-1 (forward) & 5'-TCTCCACTCGGCTTTCTTCCA-3' & 22 \\
XRCC6 (KU70) PR-2 (reverse) & 5'-TCTCCCTCCGCTTCGCACTC-3' & 20 \\
XRCC7(PRKDC) PR-1 (forward) & 5'-CGGCTGCCAACGTTCTTCC-3' & 20 \\
XRCC7(PRKDC) PR-2 (reverse) & 5'-GACATTTTTGTCAGCCAATCTT-3' & 20 \\
\hline
\end{tabular}


Table 2 PCR conditions used for polymorphisms studied

\begin{tabular}{|c|c|c|c|c|c|c|c|}
\hline & & \multicolumn{2}{|l|}{$\begin{array}{l}X R C C 5 \\
(K U 80)\end{array}$} & \multicolumn{2}{|l|}{$\begin{array}{l}X R C C 6 \\
(K U 70)\end{array}$} & \multicolumn{2}{|c|}{$\begin{array}{l}X R C C 7 \\
(P R K D C)\end{array}$} \\
\hline & & Temp & Time & Temp & Time & Temp & Time \\
\hline Initial denaturation & & $95^{\circ} \mathrm{C}$ & $5 \mathrm{~min}$ & $95^{\circ} \mathrm{C}$ & $5 \mathrm{~min}$ & $95^{\circ} \mathrm{C}$ & $5 \mathrm{~min}$ \\
\hline \multirow[t]{3}{*}{ Amplification (30 cycles) } & Annealing & $60^{\circ} \mathrm{C}$ & $30 \mathrm{~s}$ & $58^{\circ} \mathrm{C}$ & $30 \mathrm{~s}$ & $63^{\circ} \mathrm{C}$ & $30 \mathrm{~s}$ \\
\hline & Extension & $72{ }^{\circ} \mathrm{C}$ & $30 \mathrm{~s}$ & $72^{\circ} \mathrm{C}$ & $30 \mathrm{~s}$ & $72^{\circ} \mathrm{C}$ & $30 \mathrm{~s}$ \\
\hline & Denaturation & $95^{\circ} \mathrm{C}$ & $30 \mathrm{~s}$ & $95^{\circ} \mathrm{C}$ & $30 \mathrm{~s}$ & $95^{\circ} \mathrm{C}$ & $30 \mathrm{~s}$ \\
\hline Final extension & & $72^{\circ} \mathrm{C}$ & $5 \mathrm{~min}$ & $72^{\circ} \mathrm{C}$ & $5 \mathrm{~min}$ & $72^{\circ} \mathrm{C}$ & $5 \mathrm{~min}$ \\
\hline
\end{tabular}

Genotype frequencies of NHEJ polymorphism and correlation with DNA damage/repair and mRNA expression In the present study, the distribution of genotype frequencies at each of the polymorphisms was determined among 20 donors studied and correlated with DNA damage, repair and mRNA expression level.

\section{XRCC5 (KU80) polymorphism}

The genotypic frequencies of XRCC5 at $0 R / 1 R, 0 R / 2 R$, $0 \mathrm{R} / 3 \mathrm{R}, 1 \mathrm{R} / 1 \mathrm{R}, 1 \mathrm{R} / 2 \mathrm{R}, 1 \mathrm{R} / 3 \mathrm{R}, 2 \mathrm{R} / 2 \mathrm{R}$ and genotypes were $5,5,0,40,30,0,20$ and $0 \%$, respectively, among the 20 donors studied (Fig. 2a). Association of polymorphism at XRCC5 gene with the DNA damage among the 20 donors was studied. For XRCC5 (0R/1R/2R/3R) polymorphism, five genotypes $(0 R / 1 R, 0 R / 2 R, 1 R / 1 R, 1 R / 2 R$ and $2 \mathrm{R} / 2 \mathrm{R}$ ) were observed among these 20 donors.

Dose response of the genotypes at XRCC5 with respect to DNA damage and mRNA expression among the 20 donors is given in Fig. 3a. Regression analysis was performed for each polymorphism with respect to DNA damage and mRNA expression as shown in Table 4. Our results revealed that there is no significant difference in the correlation between DNA damage at various dose points and various genotypes at each gene polymorphism (Table 4). As shown in Table 4, all the genotypes observed at XRCC5 showed significant positive correlation with DNA damage at different doses studied.

Similarly, genotypes of each polymorphism was correlated with DNA repair among these 20 donors (Fig. 3b). As shown in Table 4, no significant difference in the repair pattern was observed among the genotypes observed at all the three gene polymorphisms. All the genotypes showed significant negative correlation with DNA damage and post-irradiation time, indicating no association between XRCC5 (0R/1R/2R/3R) and repair pattern among these groups (Table 4).

At XRCC5, the mRNA expression level at $0 \mathrm{~h}$ and $4 \mathrm{~h}$ post irradiation was given in Fig. 3c. As shown in Fig. $3 c$, variation was observed at dose response of mRNA expression level of XRCC5 for each genotype. Donors with genotype (0R/OR) showed increasing trend in mRNA expression level at all the doses as compared to other genotypes though not statistically significant $(P=$ 0.285). Nevertheless, correlation analysis revealed that genotype (0R/0R) showed decreased XRCC5 mRNA expression level with increasing doses $(r=-0.339, P=$ $0.512)$, whereas donors with genotype $(1 \mathrm{R} / 1 \mathrm{R})$ showed positive correlation $(r=0.464, P=0.001)$ between mRNA expression at XRCC5 andradiation doses studied. However, donors with genotype $2 \mathrm{R}$ allele showed positive correlation between mRNA expression level at XRCC5 and at different radiation doses studied (0R/2R: $r=$ 0.846, $P=0.034 ; 1 \mathrm{R} / 2 \mathrm{R}: r=0.698, P=0.0001$ and $2 \mathrm{R} / 2 \mathrm{R}$ : $r=0.831, P=0.0001$ ) (Table 4).

At XRCC5, mRNA expression was studied at $0 \mathrm{~min}$, $30 \mathrm{~min}, 60 \mathrm{~min}, 120 \mathrm{~min}$ and $240 \mathrm{~min}$ of $2.0 \mathrm{~Gy}$ post-irradiation for 20 donors as shown in the line graph (Fig. $3 d)$. As shown in Fig. 3d, genotype (0R/2R) showed increases mRNA expression level with time points as compared to other genotypes though not statistically significant $(P=0.406)$. Correlation analysis revealed variation in the level of mRNA expression of XRCC5

Table 3 Restriction enzymes and fragment sizes of polymorphisms studied

\begin{tabular}{|c|c|c|c|c|c|}
\hline Gene Name & SNP/ polymorphism & Enzyme & Genotype & Undigested product (bp) & Digested product (bp) \\
\hline XRCC5 (KU80) & $\begin{array}{l}\text { 3R/2R/1R/OR } \\
\text { (rs6147172) }\end{array}$ & - & $\begin{array}{l}0 R / 0 R \\
1 R / 1 R \\
2 R / 2 R \\
3 R / 3 R\end{array}$ & $\begin{array}{l}224 \\
245 \\
266 \\
287\end{array}$ & - \\
\hline XRCC6 (KU70) & $61 \mathrm{C} / \mathrm{G}$ & Banl & $\begin{array}{l}C / C \\
G / G\end{array}$ & 314 & $\begin{array}{l}262 \text { and } 52 \\
182,80 \text { and } 52\end{array}$ \\
\hline XRCC7 (PRKDC) & $\begin{array}{l}6721 \mathrm{G} / \mathrm{T} \\
\text { (rs7003908) }\end{array}$ & Pvull & $\begin{array}{l}\mathrm{G} / \mathrm{G} \\
\mathrm{T} / \mathrm{T}\end{array}$ & 368 & $\begin{array}{l}368 \\
274 \text { and } 94\end{array}$ \\
\hline
\end{tabular}



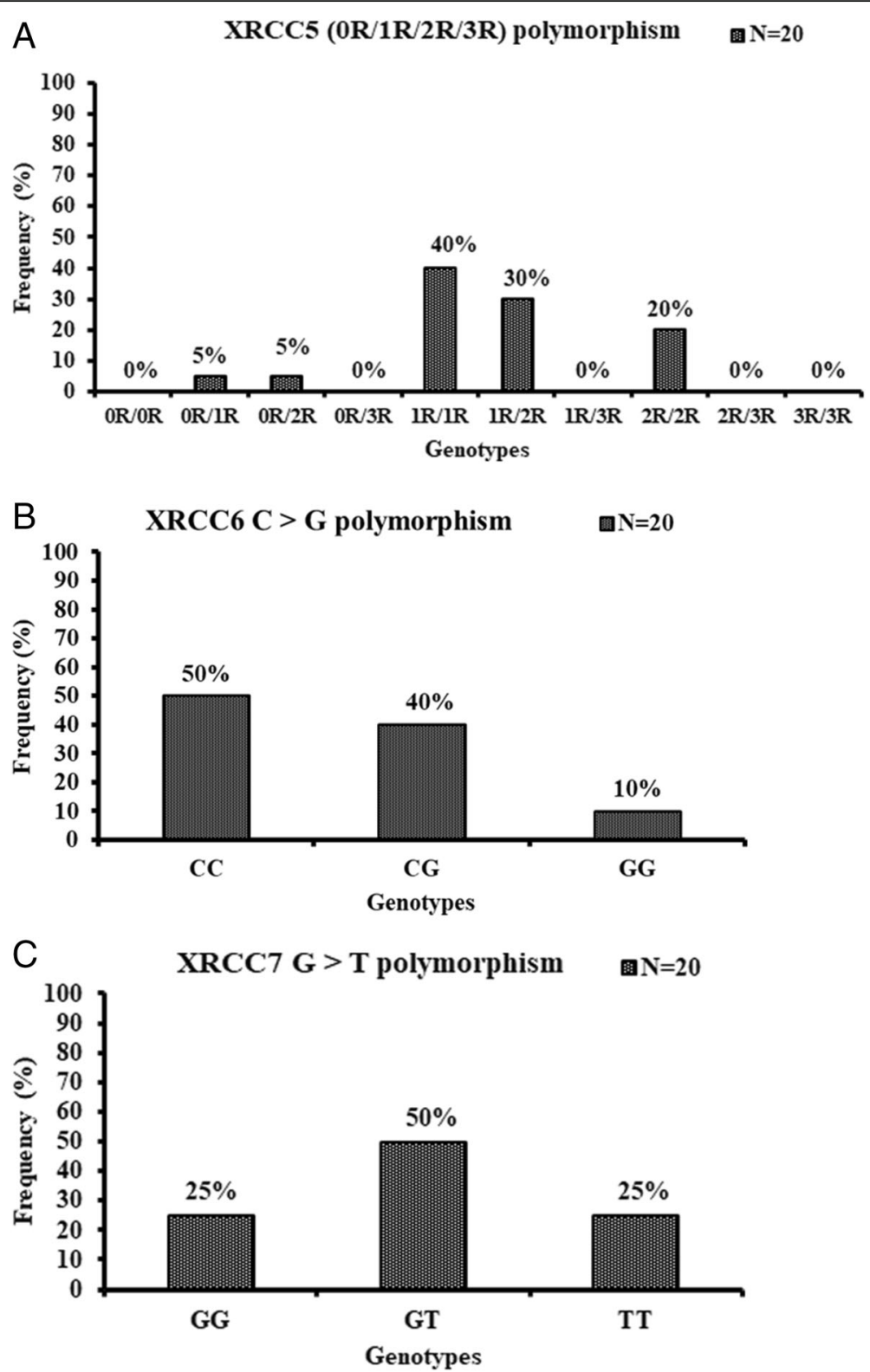

Fig. 2 Histogram representing distribution of genotype frequencies of XRCC5 (OR/1R/2R/3R), XRCC6 (C/G) and XRCC7 (G/T) polymorphisms among 20 donors studied $(N=20)$. X-axis represents different genotypes of XRCC5 (OR/1R/2R/3R) polymorphism and Y-axis represents genotypic frequency (\%)

among the genotypes observed (Table 4). Donor with genotype $(0 \mathrm{R} / 0 \mathrm{R})$ showed significant negative correlation $(r=-0.979, P=0.004)$ with mRNA expression and post-irradiation time after $2.0 \mathrm{~Gy}$. Donors with genotype $(1 \mathrm{R} / 1 \mathrm{R})$ showed positive correlation $(r=$ 0.366, $P=0.020$ ) between mRNA expression of XRCC5 and post-irradiation time points. As observed from the dose response data of XRCC5 at transcript level, donors having genotype with $2 \mathrm{R}$ allele $(0 \mathrm{R} / 2 \mathrm{R}: r=0.737, P=$ $0.019 ; 1 \mathrm{R} / 2 \mathrm{R}: r=0.562, P=0.001$ and $2 \mathrm{R} / 2 \mathrm{R}: r=0.871$, $P=0.0001)$ showed strong correlation between XRCC5
mRNA expression and post-irradiation time points as compared to other genotypes.

\section{XRCC6 (KU70) polymorphism}

For the XRCC6 $(\mathrm{C} / \mathrm{G})$ polymorphism, the frequencies of the $C / C, C / G$, and $G / G$ genotypes were 50,40 , and $10 \%$, respectively, among 20 donors (Fig. $2 \mathrm{~b}$ ). The frequencies of $\mathrm{C}$ and $\mathrm{G}$ alleles among 20 donors were observed to be 0.7 and 0.3 respectively.

Association of polymorphism at XRCC6 gene with respect to DNA damage was assessed among the 20 

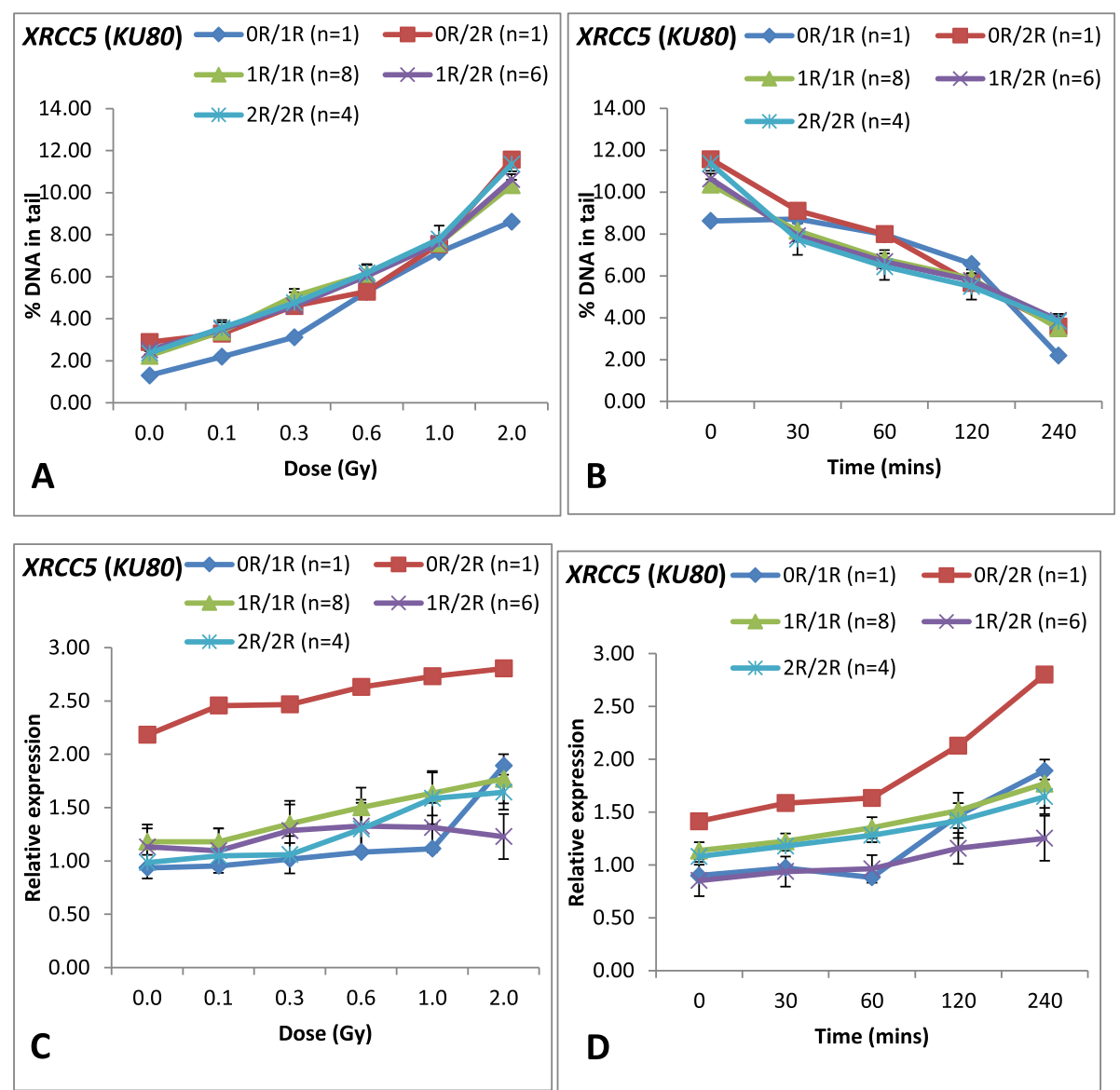

Fig. 3 Line graph showing dose response, repair kinetics and mRNA expression of XRCC5 (KU80) among 20 donors and their correlation with each genotype. a Dose response curve for DNA damage at different doses for 20 donors. X-axis represents dose (Gy) whereas Y-axis represents DNA damage (Mean \pm SEM) in terms of DNA in tail (\%). Groups were created amongst 20 donors on the basis of genotypes. $\mathbf{b}$ Repair kinetics for 20 donors at various post-irradiation time intervals. X-axis represents post-irradiation time (min) whereas Y-axis represents DNA damage (Mean \pm SEM) in terms of DNA in tail (\%). Groups were created amongst 20 donors on the basis of genotypes. c mRNA expression of XRCC5 (KU80) at different doses for 20 donors. X-axis represents dose (Gy) and Y-axis represents relative XRCC5 (KU80) mRNA expression (Mean \pm SEM) at $4 \mathrm{~h}$ post-irradiation. Groups were created amongst 20 donors on the basis of genotype. $\mathbf{d}$ mRNA expression (Mean \pm SEM) of XRCC5 (KU80) for 20 donors at different post-irradiation time. $X$-axis represents time $(\mathrm{min})$ and $Y$-axis represents relative expression. Groups were created amongst 20 donors on the basis of genotype

donors studied. For XRCC6 (C/G) polymorphism, $C / C$, $C / G$ and $G / G$ polymorphisms were observed among 20 donors. Figure $4 \mathrm{a}$ shows, dose response of the above mentioned genotypes among 20 donors studied. Regression analysis showed no significant difference observed among various genotypes in dose response study. As shown in Table 4, all the genotypes of XRCC6 polymorphism showed significant positive correlation between DNA damage and various doses, thus indicating $X R C C 6(C / G)$ polymorphism is not associated with the induction of DNA damage.

Similarly, association of genotypes of XRCC6 with respect to DNA repair was also studied among these donors. As shown in Fig. 4b, no significant difference was observed in the repair pattern among the genotypes. All the genotypes showed significantly negative correlation between the DNA damage and post-irradiation time points (Table 4).

The mRNA expression level of XRCC6 was studied at $0 \mathrm{~h}$ and $4 \mathrm{~h}$ post irradiation. Figure $4 \mathrm{c}$, shows mRNA expression level of XRCC6 at various doses studied at $4 \mathrm{~h}$ post-irradiation. As shown in Fig. 4c, dose response of XRCC6 showed variation in mRNA expression level among the genotypes. Genotypes $C / C$ and $C / G$ showed positive correlation $(C / C: r=0.486, P=0.0001$ and $C / G$ : $r=0.631, P=0.0001)$ between mRNA expression level and radiation doses, whereas $G / G$ genotype showed decreasing mRNA expression level with increasing radiation dose $(r=-0.463, P=0.129)$ (Table 4$)$.

Figure $4 \mathrm{~d}$ showed the line graph of of mRNA expression of XRCC6 at different time points up to $240 \mathrm{~min}$ for $2.0 \mathrm{~Gy}$ post-irradiation. Correlation analysis performed 
Table 4 Correlation coefficient and significance levels for XRCC5 (OR/1R/2R/3R), XRCC6 (C/G) and XRCC7 (G/T) at different biological end points

\begin{tabular}{|c|c|c|c|c|c|c|c|c|}
\hline \multirow[t]{2}{*}{ Gene name } & \multicolumn{2}{|c|}{$\begin{array}{l}\text { ADNA damage at } \\
\text { different doses }\end{array}$} & \multicolumn{2}{|c|}{$\begin{array}{l}\text { BmRNA expression at } \\
4 \mathrm{~h} \text { post-irradiation } \\
\text { with different doses }\end{array}$} & \multicolumn{2}{|c|}{$\begin{array}{l}{ }^{C} \text { DNA repair at different } \\
\text { post-irradiation time points }\end{array}$} & \multicolumn{2}{|c|}{$\begin{array}{l}\text { DmRNA expression at various } \\
\text { post-irradiation time points }\end{array}$} \\
\hline & $r$ & $\mathbf{P}$ & $r$ & $\mathbf{P}$ & $r$ & $\mathbf{P}$ & $r$ & $\mathbf{P}$ \\
\hline \multicolumn{9}{|c|}{ XRCC5 (0R/1R/2R/3R) } \\
\hline OR/OR & $0.971^{* *}$ & 0.001 & -0.339 & 0.512 & $-0.939^{*}$ & 0.018 & $-0.979^{* *}$ & 0.004 \\
\hline $0 R / 2 R$ & $0.986^{* *}$ & 0.0001 & $0.846^{*}$ & 0.034 & $-0.900^{*}$ & 0.038 & $0.737^{*}$ & 0.019 \\
\hline $1 R / 1 R$ & $0.947^{* *}$ & 0.0001 & $0.464^{* *}$ & 0.001 & $-0.859^{* *}$ & 0.0001 & $0.366^{*}$ & 0.020 \\
\hline $1 R / 2 R$ & $0.967^{* *}$ & 0.0001 & $0.698^{* *}$ & 0.0001 & $-0.879^{* *}$ & 0.0001 & $0.562^{* *}$ & 0.001 \\
\hline $2 R / 2 R$ & $0.916^{* *}$ & 0.0001 & $0.831^{* *}$ & 0.0001 & $-0.906^{* *}$ & 0.0001 & $0.871^{* *}$ & 0.0001 \\
\hline \multicolumn{9}{|l|}{$X R C C 6$ (C/G) } \\
\hline $\mathrm{CC}$ & $0.940^{* *}$ & 0.0001 & $0.486^{* *}$ & 0.0001 & $-0.892^{* *}$ & 0.0001 & $0.364^{* *}$ & 0.009 \\
\hline CG & $0.946^{* *}$ & 0.0001 & $0.631^{* *}$ & 0.0001 & $-0.859^{* *}$ & 0.0001 & $0.433^{* *}$ & 0.005 \\
\hline GG & $0.970^{* *}$ & 0.0001 & -0.463 & 0.129 & $-0.879^{* *}$ & 0.001 & -0.581 & 0.078 \\
\hline \multicolumn{9}{|l|}{$X R C C 7(\mathrm{G} / \mathrm{T})$} \\
\hline GG & $0.963^{* *}$ & 0.0001 & 0.086 & 0.650 & $-0.892^{* *}$ & 0.0001 & $0.199^{*}$ & 0.048 \\
\hline GT & $0.947^{* *}$ & 0.0001 & -0.020 & 0.879 & -0.868 & 0.0001 & 0.100 & 0.489 \\
\hline $\mathrm{TT}$ & $0.954^{* *}$ & 0.0001 & $-0.376^{*}$ & 0.041 & $-0.878^{* *}$ & 0.0001 & $-0.290^{*}$ & 0.020 \\
\hline
\end{tabular}

Correlation coefficient and significance levels at XRCC5 (OR/1R/2R/3R), XRCC6 (C/G) and XRCC7 (G/T) polymorphism. A. DNA damage at different dose groups, B. mRNA expression at $4 \mathrm{~h}$ post-irradiation, C. DNA repair at different post-irradiation time points D. mRNA expression at various post-irradiation time. $\left.{ }^{* *}\right)$ and $\left({ }^{*}\right)$ indicates sigificant correlation $(P<0.01)$ and $(P<0.05)$ respectively

at XRCC6 for mRNA expression in different genotypes is given in Table 4. As evident in Fig. 4d, donors having $C / C$ and $C / G$ genotypes showed significant positive correlation $(\mathrm{C} / \mathrm{C}: r=0.364, P=0.009$ and $\mathrm{C} / \mathrm{G}: r=0.433$, $P=0.005$ ) between mRNA expression and post-irradiation time points. Donors with $G / G$ genotype showed negative correlation $(r=-0.581, P=0.078)$ between mRNA expression and post-irradiation time after $2.0 \mathrm{~Gy}$, which was not statistically significant.

\section{XRCC7 (PRKDC) polymorphism}

For XRCC7 G/T polymorphism, the frequencies of the $G / G, G / T$ and $T / T$ genotypes were 25,50 , and $25 \%$, respectively, among the 20 donors studied (Fig. 2c). The frequencies of $\mathrm{G}$ and $\mathrm{T}$ alleles among 20 donors were observed to be 0.5 and 0.5 respectively. Association of polymorphism at $X R C C 7$ gene with the DNA damage among the 20 donors was assessed. Figure 5a showed dose response of the genotypes among 20 donors with respect to DNA damage and mRNA expression level. Regression analysis showed that there was no significant difference among the genotypes observed in the dose response study. As shown in Table 4, all the genotypes of XRCC7 polymorphism showed significant positive correlation between DNA damage and dose groups studied.

Similarly, association of polymorphism with DNA repair was assessed among these donors. As shown in Fig. 5b, we did not observe any significant difference in the repair pattern among different genotypes. All the genotypes showed significantly negative correlation between the DNA damage and post-irradiation time as shown in Table 4.

The mRNA expression of $X R C C 7$ was studied at $0 \mathrm{~h}$ and $4 \mathrm{~h}$ post irradiation. Figure $5 \mathrm{c}$, showed mRNA expression of $X R C C 7$ at different doses studied at $4 \mathrm{~h}$ post-irradiation and inter-individual variation was observed. As shown in Fig. $5 c$, there was also variation observed in the dose response of $X R C C 7 \mathrm{mRNA}$ expression profile with respect to each of the genotypes. The genotypes GG and GT showed no significant correlation $(G / G: r=$ $0.086, P=0.650$ and $G / T: r=-0.020, P=0.879$ ) between $X R C C 7$ mRNA expression and radiation doses, whereas genotype $T / T$ showed decreasing mRNA expression at XRCC7 with increasing doses $(r=-0.376$, $P=0.041)$ (Table 4).

Figure $5 \mathrm{~d}$ showed the line graph of mRNA expression of XRCC7 at $0 \mathrm{~min}, 30 \mathrm{~min}, 60 \mathrm{~min}, 120 \mathrm{~min}$ and 240 min of 2.0 Gy post-irradiation for 20 donors. Correlation analysis showed variation at the level of mRNA expression of XRCC7 among the genotypes (Table 4). As observed for dose response of XRCC7 at transcript level, donors with $(G / G)$ and $(G / T)$ genotypes showed no significant correlation (G/G: $r=0.199, P=0.048$ and $G / T$ : $r=0.100, \quad P=0.489$ ) between mRNA expression of $X R C C 7$ and post-irradiation time points. Donors with $(T / T)$ genotype showed negative correlation $(r=-0.290$, $P=0.020)$ between mRNA expression of XRCC7 and post-irradiation time points after $2.0 \mathrm{~Gy}$ of irradiation, which was not statistically significant. 

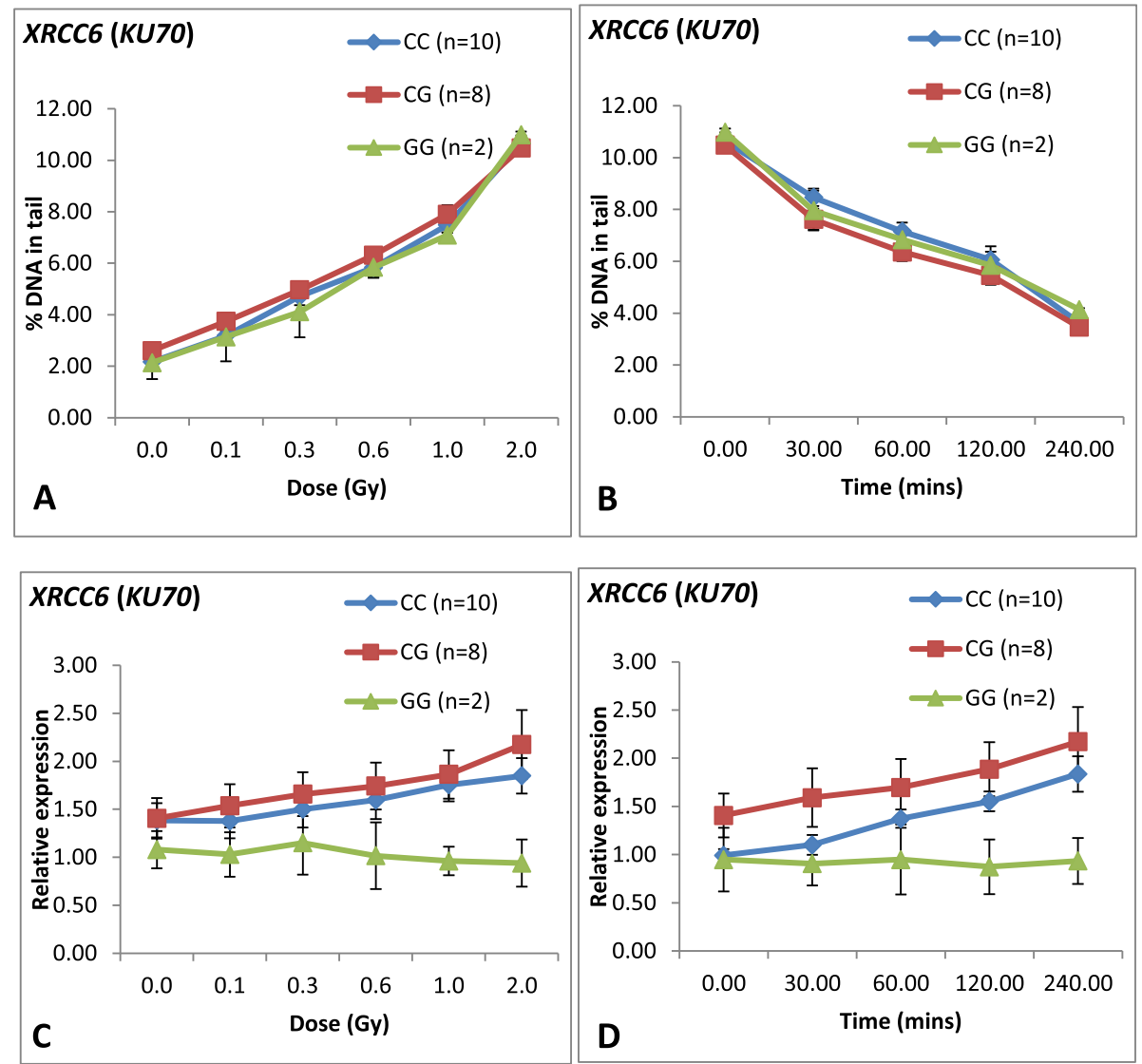

Fig. 4 Line graph showing dose response, repair kinetics and mRNA expression of XRCC6 (KU70) among 20 donors and their correlation with each genotype. a Dose response curve for DNA damage at different doses for 20 donors. X-axis represents dose (Gy) whereas Y-axis represents DNA damage (Mean \pm SEM) in terms of DNA in tail (\%). Groups were created amongst 20 donors on the basis of genotypes. $\mathbf{b}$ Repair kinetics for 20 donors at various post-irradiation time intervals. X-axis represents post-irradiation time (min) whereas Y-axis represents DNA damage (Mean \pm SEM) in terms of DNA in tail (\%). Groups were created amongst 20 donors on the basis of genotypes. c mRNA expression of XRCC6 (KU70) at different doses for 20 donors. X-axis represents dose (Gy) and Y-axis represents relative XRCC6 (KU70) mRNA expression (Mean \pm SEM) at $4 \mathrm{~h}$ post-irradiation. Groups were created amongst 20 donors on the basis of genotype. $\mathbf{d}$ mRNA expression (Mean \pm SEM) of XRCC6 (KU70) for 20 donors at different post-irradiation time. $X$-axis represents time (min) and Y-axis represents relative expression. Groups were created amongst 20 donors on the basis of genotype

RAR and association of genotypes of adaptive and nonadaptive donors with DNA damage, repair and mRNA expression

RAR study was performed in primed (cells exposed with a priming dose of 0.1 Gy followed by $2.0 \mathrm{~Gy}$ after $4 \mathrm{~h}$ incubation) and non-primed cells (cells exposed with a 2.0 Gy) among 20 healthy donors. Sixteen of them showed significant reduction of DNA damage in primed cells (cells exposed with a priming dose of 0.1 Gy followed by $2.0 \mathrm{~Gy}$ after $4 \mathrm{~h}$ incubation) and are called as adaptive donors, whereas four donors did not show any significant reduction of DNA damage and are called as nonadaptive donors. In the present study, emphasis was given to study association of the genotypes of XRCC5, $X R C C 6$ and $X R C C 7$ with the adaptive and non-adaptive donors with respect to DNA damage, repair and mRNA expression profile in primed and non-primed cells. Figure 6 is a representation of individual donors showing or not showing radio-adaptive response at DNA damage level.

Table 5 shows average DNA damage at $2.0 \mathrm{~Gy}$, average percentage of repair at $2.0 \mathrm{~Gy}$ after $4 \mathrm{~h}$ post irradiation and average relative mRNA expression at $2.0 \mathrm{~Gy}$ after 4 $\mathrm{h}$ post irradiation for XRCC5, XRCC6 and XRCC7. As shown in Table 5 , average DNA damage at 2.0 Gy was observed to be significantly higher in non-adaptive donors as compared to adaptive donors for each of the genotypes of the polymorphisms studied. However, there was no significant difference in average DNA damage, repair and mRNA expression level among the genotypes of XRCC5, XRCC6 and XRCC7 polymorphisms among each group (adaptive or non-adaptive donors). But the repair percentage was comparatively higher among nonadaptive donors.

But when compared between adaptive and non-adaptive donors in non-primed cells at $2.0 \mathrm{~Gy}$, the genotypes $1 \mathrm{R} /$ 

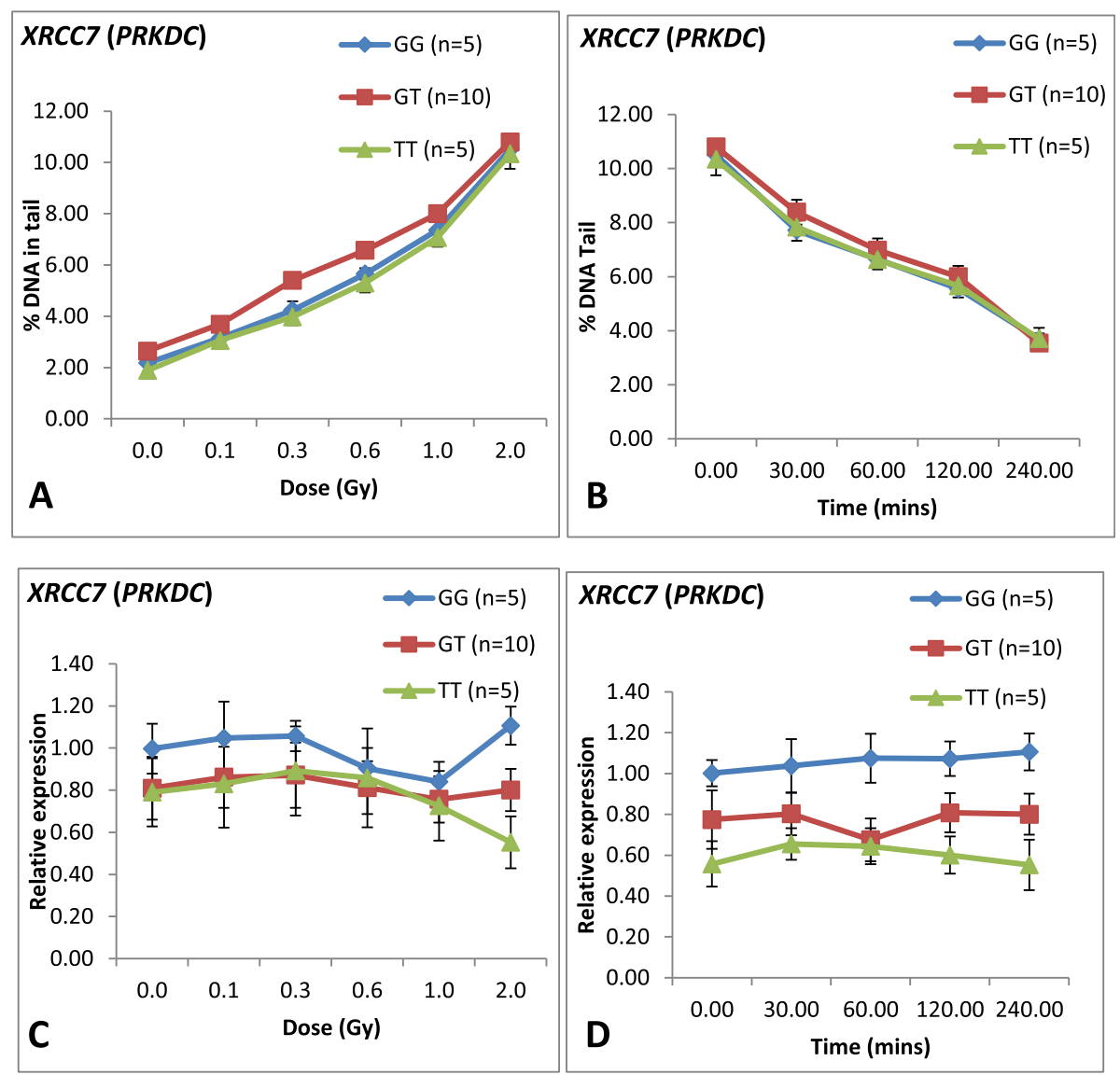

Fig. 5 Line graph showing dose response, repair kinetics and mRNA expression of XRCC7 (PRKDC) among 20 donors and their correlation with each genotype. a Dose response curve for DNA damage at different doses for 20 donors. X-axis represents dose (Gy) whereas Y-axis represents DNA damage (Mean \pm SEM) in terms of DNA in tail (\%). Groups were created amongst 20 donors on the basis of genotypes. $\mathbf{b}$ Repair kinetics for 20 donors at various post-irradiation time intervals. X-axis represents post-irradiation time (min) whereas Y-axis represents DNA damage (Mean \pm SEM) in terms of DNA in tail (\%). Groups were created amongst 20 donors on the basis of genotypes. c mRNA expression of XRCC7 (PRKDC) at different doses for 20 donors. X-axis represents dose (Gy) and Y-axis represents relative XRCC7 (PRKDC) mRNA expression (Mean \pm SEM) at $4 \mathrm{~h}$ post-irradiation. Groups were created amongst 20 donors on the basis of genotype. $\mathbf{d}$ mRNA expression (Mean \pm SEM) of XRCC7 (PRKDC) for 20 donors at different post-irradiation time. $X$-axis represents time (min) and Y-axis represents relative expression. Groups were created amongst 20 donors on the basis of genotype

2R of XRCC5 showed similar mRNA expression among the adaptive vs non-adaptive donors $(1.04 \pm 0.13$ vs $1.04 \pm$ $0.0)$. There was also significant difference $(p<0.05)$ in the percentage of DNA damage (\%T) among adaptive vs nonadaptive donors. At XRCC6 polymorphism, donors with $C / C$ and $C / G$ genotypes showed significantly higher $(P<$ $0.05)$ mRNA expression level among adaptive donors as compared to non-adaptive donors (C/C: $1.24 \pm 0.40$ vs1.03 $\pm 0.24 ; C / G: 1.27 \pm 0.22$ vs $0.95 \pm 0.00)$. At $X R C C 7$, all the three genotypes (TT, TG and $G G$ ) did not show significant mRNA expression level among adaptive vs nonadaptive donors as shown in Table 5 .

Distribution of genotypes at XRCC5, XRCC6 and $X R C C 7$, average DNA damage and relative expression in primed cells (adaptive donors) and non-primed cells (non-adaptive donors) are given in Table 6. As shown in Table 6, average DNA damage in primed cells (cells exposed with $0.1 \mathrm{~Gy}$ followed by a challenge dose of at $2.0 \mathrm{~Gy})$ showed significantly higher percentage of DNA damage $(\% \mathrm{~T})$ among non-adaptive donors as compared to adaptive donors for each of the genotypes of the polymorphisms studied. At XRCC5, the genotypes $1 \mathrm{R} / 1 \mathrm{R}$ and $1 R / 2 R$ showed no significant difference in mRNA expression level in primed cells of adaptive vs non adaptive donors $(1 \mathrm{R} / 1 \mathrm{R}: 1.09 \pm 0.31$ vs $1.12 \pm 0.00 ; 1.04 \pm 0.13$ vs $1.04 \pm 0.0$ ). However, at XRCC6, the donors with C/G genotype showed significantly increased $(P<0.05)$ mRNA expression in primed cells among adaptive vs non-adaptive donors (C/G: $1.22 \pm 0.26$ vs $0.95 \pm 0.00$ ). It showed significantly higher $\%$ of DNA damage in primed cells of non-adaptive donors as compared to adaptive donors. At $\mathrm{XRCC7}$, mRNA expression is marginally higher in primed cells of adaptive donors as compared to non-adaptive donors for $\mathrm{G} / \mathrm{G}$ genotype. But higher \% 


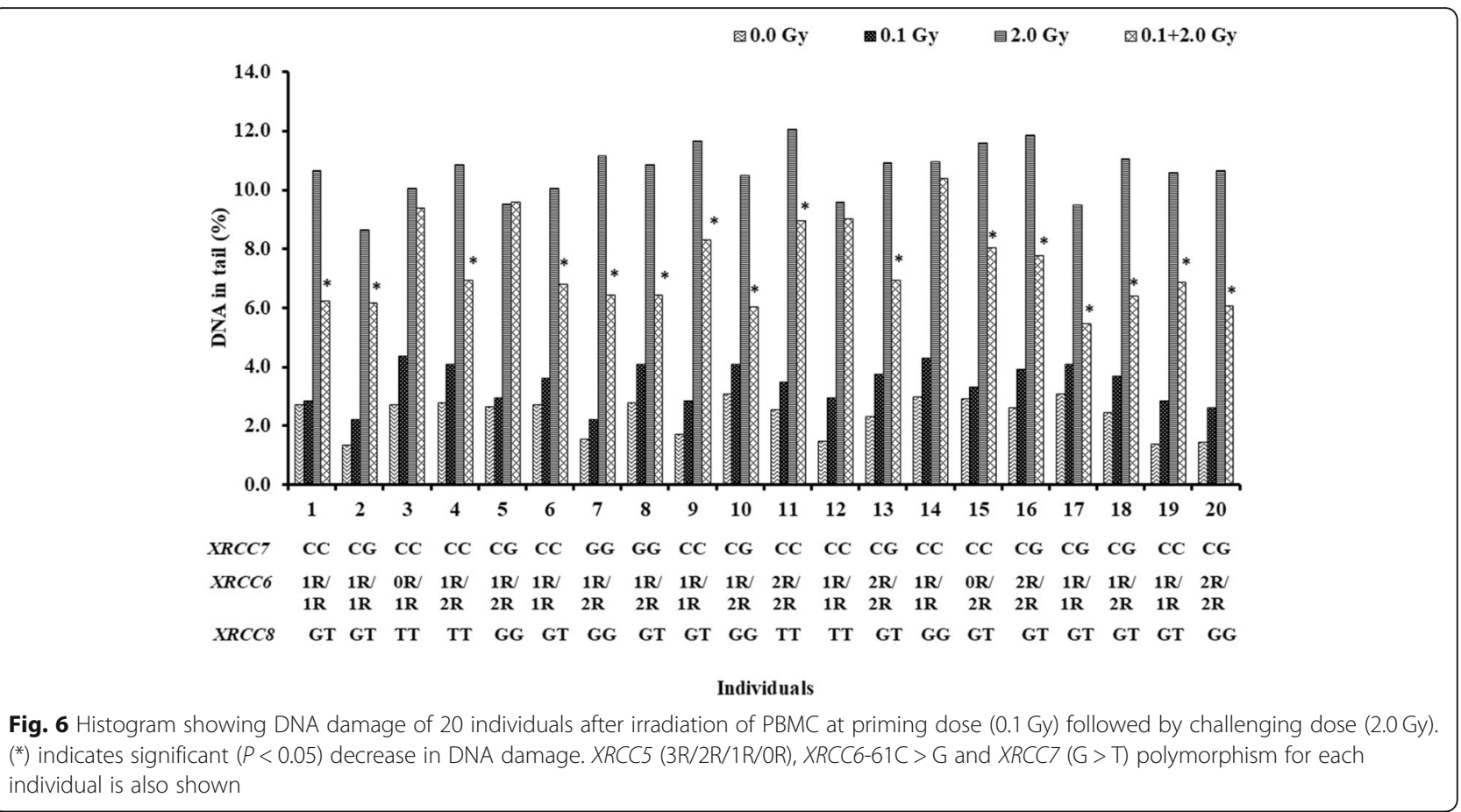

of DNA damage was observed among non-adaptive donors as compared to adaptive donors.

\section{Discussion}

DSBs are one of the most lethal DNA lesions induced by IR, as well as endogenous reactive oxygen species (ROS) [34], which are mainly repaired through non-homologous end joining (NHEJ) repair pathway in circulating lymphocytes. Ku proteins (Ku70 and Ku80) proteins play crucial role in NHEJ repair. $\mathrm{Ku}$ is a heterodimer composed of $69 \mathrm{kD}$ and $83 \mathrm{kD}$ polypeptides, which initiates DSB repair process by binding to the broken DNA ends and recruits the DNA-PK catalytic subunit (DNA-PKcs) to form the active DNA-PK enzyme. The active DNA-PK enzyme, through its kinase activity recruit other enzymes, such as Artemis, that process and join the broken ends [35]. Ku proteins also take part in DNA replication, apoptotic signaling and telomere maintenance [36]. Ku70 and Ku80 genes are very active during $G_{0} / G_{1}$ and early S-phase of the cell cycle [37-39].

DDR induced by genotoxic stress including IR lead to alteration of gene expression profile in human cells [17, 18]. Several studies have demonstrated early and late responses of miRNA expression of several genes involved in various cellular and molecular processes in human cells in response to IR. Transcriptional profiling of DNA repair genes is used as a biomarker for radiation exposure and has been used to gain insight into the molecular mechanisms induced by low dose exposures in a variety of cell types for e.g. cell cultures of human myeloid cells [40-42].
However, limited studies are available, where transcriptional expression of NHEJ repair genes have been studied in peripheral blood mononuclear cells. Earlier, we had demonstrated dose response, RAR and time dependent studies which have shown alteration in transcript profile of NHEJ genes in resting PBMCs [21]. Post irradiation changes at mRNA transcription level at early time points provides information on transcriptional regulation and DNA repair response in human PBMC exposed to IR. In the present study, post irradiation time point changes were quantitated at mRNA level up to $240 \mathrm{~min}(4 \mathrm{~h})$, which showed individual variation. Similarly, DNA damage and repair kinetics among 20 donors have also shown high degree of inter-individual variation. Hence, it is interesting to correlate NHEJ polymorphism of XRCC5, XRCC6 and XRCC7 with DNA damage and mRNA expression.

Several studies have been carried out to find out the role of cellular activities involving the action of DNA repair and cell cycle checkpoints [43-45]. Individual sensitivity to IR is a key cellular phenomenon for DNA repair and signaling of cell cycle checkpoints. Several studies have been carried out on DDR, DNA repair and cell cycle checkpoints [43, 46, 47]. Individual variation may contribute towards radio-sensitivity in a population [48]. Radio-resistance helps cells to repair DNA damage efficiently [49]. In the present study, some of the genotypes of NHEJ polymorphisms showed association with increased mRNA expression at XRCC5, XRCC6 and XRCC7. 


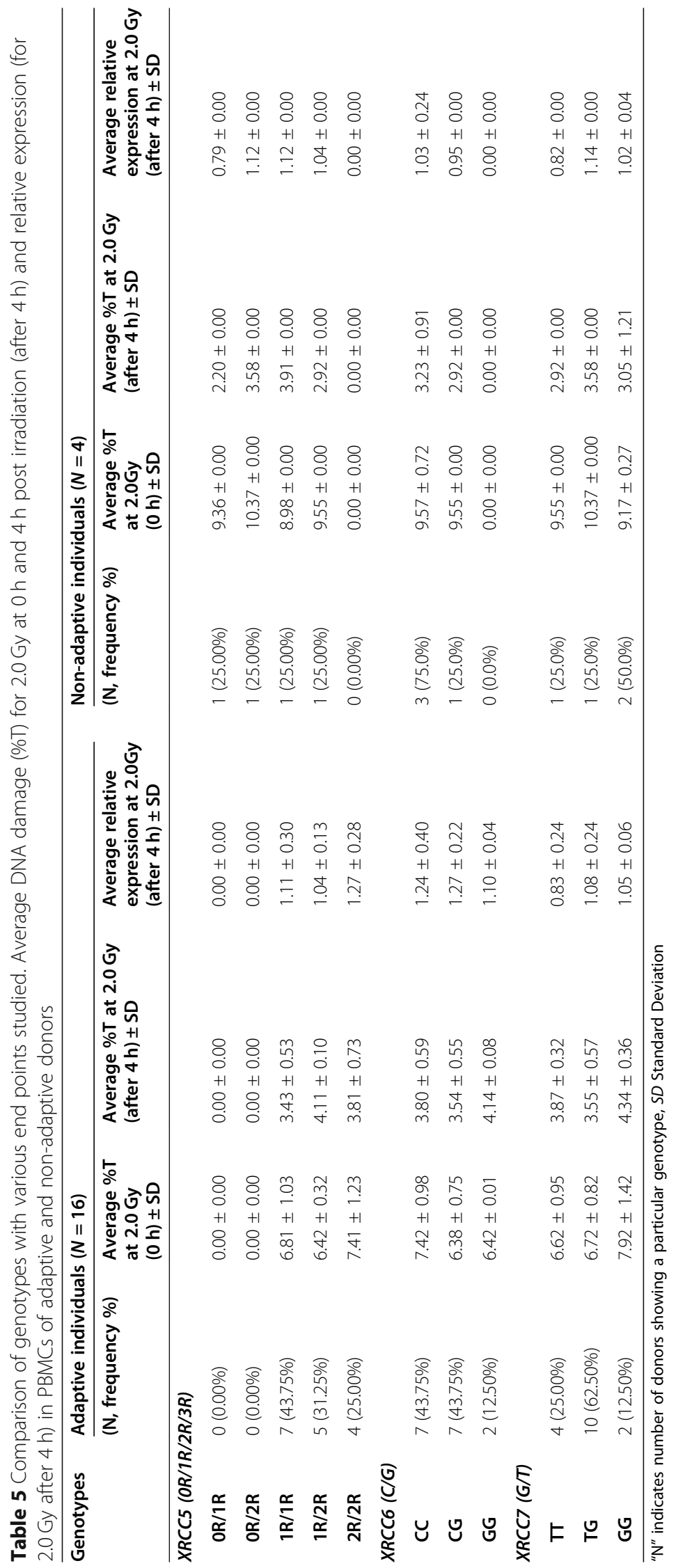




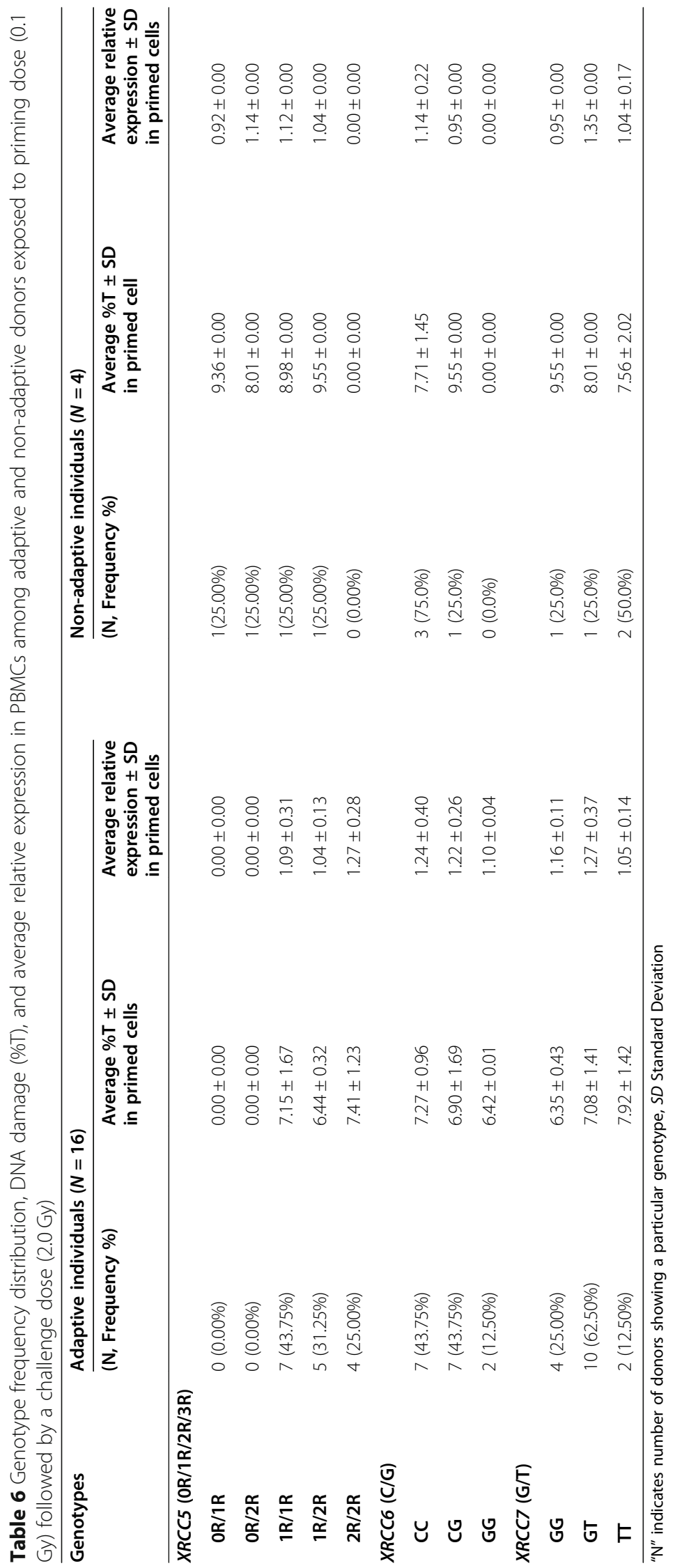


Some of the DNA repair gene polymorphism such as $\mathrm{XPC}, \mathrm{XRCC} 1$ has shown significant correlations between genotypes and induced DNA damages. For instance, at XPC (Lys939Gln and Ala499Val) polymorphism where the haplotypes "T-A" (in the order of Ala499Val-PATLys939Gln) was associated with the lowest DNA damages, thus suggesting that the DNA repair capacity of host cells might be modulated by specific $X P C$ polymorphisms [30]. Similarly, Cornetta et al., reported that polymorphisms in XRCC1 DNA repair genes could influence individual DNA repair capacity [50]. However, limited data is available regarding the association of DNA polymorphism with DNA damage, repair and mRNA expression at NHEJ genes among healthy donors.

The promoter of XRCC5 contains seven copies of cis elements, which are essential for basal expression and are involved in CpG methylation [51]. Studies pertaining to this predicted that this VNTR polymorphism, which includes a variable number of Sp1-binding motifs, that might be influencing the transcriptional activity of $X R C C 5$, which lead to a phenotypic variation that could affect susceptibility to cancer [22]. Furthermore, fewer tandem repeats in the promoter of XRCC5 was associated with enhanced levels of the XRCC5 protein in bladder cancer patients [22]. However, DNA damage and repair kinetics among these groups were not significantly different. In the present study, association between XRCC5 (3R/2R/1R/0R) polymorphism and its mRNA expression showed significant positive correlation for (2R) allele at various doses and post-irradiation time intervals.

There are reports which show that XRCC6-61C/G polymorphism is associated with an increased risk of cancers, including breast cancer and gliomas [27]. Our results on XRCC6 $(\mathrm{C} / \mathrm{G})$ polymorphism studies indicate significant positive correlation of the XRCC6 transcript level with various irradiation doses as well as postirradiation time for wild type allele (C), however, XRCC6 transcript level was negatively correlated for variant (G) allele. Accordingly, radiation induced DNA damage was observed to be lower in donors with polymorphic group containing $(\mathrm{C})$ allele as compared to the polymorphic group containing $(G)$ allele. Consequently, DNA repair was faster in donors with polymorphic group containing (C) allele as compared to the polymorphic group containing $(G)$ allele. All these findings indicate that wild type (G) allele may be associated with the radiosensitivity and DNA repair capacity of an individual.

DNA polymorphism at G6721T of XRCC7 (rs7003908) is located in the intron 8 of the gene and may play a role in regulating splicing and therefore cause mRNA instability [52, 53]. NHEJ is the major pathway for DSB repair in human cells [54]. Few studies have shown association of G6721T polymorphism of XRCC7 with several types of cancers [28, 55-60]. Our results on XRCC7 (G/T) polymorphism indicate no significant correlation of the $X R C C 7$ transcript level with different dose groups as well as post-irradiation time for wild type allele (G). However, XRCC7 transcript level was negatively correlated for variant $(\mathrm{T})$ allele. Despite these variations in the transcript levels, the radiation induced DNA damage and its repair was not significantly different among these genotypes.

In summary, our studies on association of XRCC5 (3R/2R/1R/0R), XRCC6 (C/G) and XRCC7 (G/T) polymorphism with DNA damage, repair capacity and its mRNA expression showed that wild type (G) allele may be associated with the radio-sensitivity and DNA repair capacity of an individual. At the transcript level, (2R) allele of XRCC5 polymorphism and (T) allele of $X R C C 7$ polymorphism also showed significant association at various doses of IR and post-irradiation time intervals.

It is quite intriguing that individual variation due to intrinsic DNA repair capacity decides the fate of a person's disease status. While DNA repair assays are required to be considered as potential clinical tools for prevention or treatment of disease of an individual [10], genetic variation studies provide important information towards radio-sensitivity as well as susceptibility towards a disease through DNA repair gene polymorphism. Hence, it is necessary to conduct genetic variation studies involving multiple DNA repair pathways to find out susceptibility of individual capacity to overcome the radio-sensitivity during radiotherapeutic treatments. It will be therefore important to integrate high throughput assays such as genome wide association studies, SNP profiling using next generation sequencing, global transcriptome, methylome and proteomic profiles along with restriction enzyme based SNP/VNTR assays to identify suitable biomarkers for radiation exposure in health care system to reach to the clinics as well as population based studies.

The present study demonstrated that radio-adaptive experiments showed changes at transcript level among adaptive donors in many of the genotypes as compared to non-adaptive donors. However, further studies at post-translational modification and proteomics level are required to understand the cause of genetic variability. Radio-sensitivity is an important aspect for patients undergoing radio-therapeutic treatments as efficacy of chemotherapy as well as radiation therapy depends upon individual response, which can decide treatment dosages and time span of treatment required. The present study also assessed the role of NHEJ repair gene polymorphism in RAR. 


\section{Conclusions}

DNA DSBs are highly deleterious and involvement of NHEJ repair gene polymorphism are of high importance for genome integrity. Further, high throughput studies on larger number of gene polymorphisms may be helpful for studying radio-sensitivity studies. NHEJ repair gene polymorphisms play an important role in RAR and thus can be used as potential biomarkers to identify radiosensitive and radio-resistant individuals in a population as well as among cancer patients undergoing radio-therapeutic treatments.

\section{Acknowledgments}

We are very much thankful to the volunteers who have participated in the study. We also profusely thank Ms. Prabhu J. A. and Mr. Sangram Kamble for helping us in collecting the blood samples from BARC dispensary, Trombay, Mumbai.

\section{Authors' contributions}

Shridevi Shelke (SS) and Birajalaxmi Das (BD). BD conceived the concept, designed and supervised the experiment. SS performed the experiment, SS and $\mathrm{BD}$ analyzed the data. BD interpreted the results. SS and BD are involved in writing the manuscript. BD reviewed the manuscript. The author(s) read and approved the final manuscript.

\section{Authors' information}

Dr. Mrs. Birajalaxmi Das, MPhil. PhD. Dr. Das is the Head of Low Level Radiation studies Section \& Professor, Homi Bhabha National Institute (HBNI), Anushaktinagar, Mumbai, Radiation Biology \& Health Sciences Division, Bio-Science Group, Bhabha Atomic Research Centre, Trombay, Mumbai 400 085, India.

Dr. Mrs. Shridevi Shelke, is presently a Research scientist, BSDT's Integrated Cancer Research Centre, Wagholi, Pune, India.

\section{Funding}

The research work was funded by Bhabha Atomic Research Centre, Trombay, Mumbai - 400085, India.

\section{Availability of data and materials}

Data will be available on special request to corresponding author.

\section{Ethics approval and consent to participate}

All the volunteers had given their written informed consent to participate in the study, which was approved by Medical ethics committee, Trombay, Bhabha Atomic Research Centre, Trombay, Mumbai.

\section{Consent for publication}

Both the authors have given their consent for publication.

\section{Competing interests}

The authors declare there is no competing interests.

Received: 13 September 2020 Accepted: 5 February 2021

Published online: 08 March 2021

\section{References}

1. Lomax M, Folkes L, O'Neill P. Biological consequences of radiation-induced DNA damage: relevance to radiotherapy. Clin Oncol. 2013;25:578-85.

2. Luijtena MNH, Lee JXT, Crasta KC. Mutational game changer: Chromothripsis and its emerging relevance to Cancer. Mutat Res. 2018;777:29-51.

3. Toulany M. Targeting DNA Double-Strand Break Repair Pathways to Improve Radiotherapy Response. Genes. 2019;10(1):25. https://doi.org/10.33 90/genes 10010025.

4. Devic C, Melanie LF, Nicolas F. Influence of individual radio-sensitivity on the adaptive response phenomenon: toward a mechanistic explanation based on the Nucleo-shuttling of ATM protein. Dose Response. 2018;16:1-11.
5. Toprani SM, Das B. Radio-adaptive response, individual radio-sensitivity and correlation of base excision repair gene polymorphism (hOGG1, APE1 XRCC1 and LIGASE1) in human peripheral blood mono-nuclear cells exposed to gamma radiation. Environ Mol Mutagen. 2020;61(5):551-9.

6. Brandsma I, van Gent DC. Pathway of choice in DNA double strand break repair: observations of a balancing act. Genome Integr. 2012;3(1):9. https:// doi.org/10.1186/2041-9414-3-9.

7. Li-Ping Z, Luan H, Dong X-H, Jin G-J, Man D-L, Shang H. Association between XRCC5, 6 and 7 gene polymorphisms and the risk of breast Cancer: a HuGE review and meta-analysis. Asian Pacific J Cancer Prev. 2012; 13:3637-43.

8. O'Driscol M. Diseases associated with defective responses to DNA damage. Cold Spring Harb Perspect Biol. 2012;4(12):a012773. https://doi.org/10.1101/ cshperspect.a012773.

9. Chistiakov DA, Voronova NV, Chistiakov PA. Genetic variations in DNA repair genes, radio-sensitivity to cancer and susceptibility to acute tissue reactions in radiotherapy-treated cancer patients. Acta Oncol. 2009:47(5):809-24.

10. Nagel ZD, Chaim IA, Samson LD. Inter-individual variation in DNA repair capacity: a need for multi-pathway functional assays to promote translational DNA repair research. DNA Repair. 2014;19:199-213.

11. Saini D, Sudheer KR, Vivek Kumar PR, Soren DC, Jain V, Koya PKM, Jaikrishan $G$, Das B. Evaluation of the influence of chronic low-dose radiation on DNA repair gene polymorphisms [XRCC1, XRCC3, PRKDC (XRCC7), LIG1, NEIL1] in individuals from normal and high-level natural radiation areas of Kerala coast. Int J Radiat Biol. 2020;96(6):734-9.

12. Sterpone S, Cozzi R. (2010) Influence of XRCC1 genetic polymorphisms on ionizing radiation-induced DNA damage and repair. J Nucleic Acids. 2020; 780369:1-6. https://doi.org/10.4061/2010/780369.

13. Berwick $M$, Vineis $P$. Markers of DNA repair and susceptibility to cancer in humans: an epidemiological review. J Nat Cancer Inst. 2000:91:874-97.

14. Setlow RB. Variations in DNA repair among people. In: Epidemiology and Quantitation of Environmental risk in Humans from Radiation and other agents, Part of the NATO ASI Series book series, vol. 96; 1985. p. 205-12.

15. Yu X, Wang H, Wang P, Chen BP, Wang Y. The Ku dependent nonhomologous end-joining pathway contributes to low-dose radiationstimulated cell survival. J Cell Physiol. 2011;226:369-74.

16. Jain V, Saini D, Kumar PRV, Jaikrishan G, Das B. Efficient repair of DNA double strand breaks in individuals from high level natural radiation areas of Kerala coast, south-West India. Mutat Res. 2017:806:39-50.

17. Jain V, Das B. Global transcriptome profile reveals abundance of DNA damage response and repair genes in individuals from high level natural radiation areas of Kerala coast. PLoS One. 2017;12(11):e0187274.

18. Saini D, Shelke S, Mani Vannan A, Toprani S, Jain V, Das B, Seshadri M. Transcription profile of DNA damage response genes at G0 lymphocytes exposed to gamma radiation. Mol Cell Biochem. 2012;364:271-81.

19. Toprani SM, Das B. Role of base excision repair genes and proteins in gamma-irradiated resting human peripheral blood mononuclear cells. Mutagenesis. 2015a:30:247-61.

20. Toprani SM, Das B. Radio-adaptive response of base excision repair genes and proteins in human peripheral blood mononuclear cells exposed to gamma radiation. Mutagenesis. 2015b;30:663-76.

21. Shelke S, Das B. Dose response and adaptive response of nonhomologous end joining repair genes and proteins in resting human peripheral blood mononuclear cells exposed to $\mathrm{y}$ radiation. Mutagenesis. 2015;30:365-79.

22. Wang S, Wang M, Yin S, Fu G, Li C, Chen R, Li A, Zhou J, Zhang Z, Liu Q. A novel variable number of tandem repeats (VNTR) polymorphism containing Sp1 binding elements in the promoter of XRCC5 is a risk factor for human bladder cancer. Mutat Res. 2007:638:26-36.

23. Wang G, Wang S, Shen Q, Yin S, Li C, Li A, Li J, Zhou J, Liu Q. Polymorphisms in XRCC5, XRCC6, XRCC7 genes are involved in DNA double-strand breaks (DSBs) repair associated with the risk of acute myeloid leukemia(AML) in Chinese population. J Nanjing Med Univ. 2009:23(2):93-9.

24. Gorre M, Mohandas PE, Kaqita S, Annamaneni S, Diqumarti R, Satti V. Association of XRCC5 VNTR polymorphism with the development of chronic myeloid leukemia. Tumour Biol. 2014;35(2):923-7.

25. Rajaei M, Saadat I, Omidvari S, Saadat M. Association between polymorphisms at promoters of XRCC5 and XRCC6 genes and risk of breast cancer. Med Oncol. 2014;31(4):885. https://doi.org/10.1007/s12032014-0885-8 
26. Fu YP, Yu JC, Cheng TC, Lou MA, Hsu GC, Wu CY, Chen ST, Wu HS, Wu PE, Shen CY. Breast cancer risk associated with genotypic polymorphism of the non-homologous end-joining genes: a multigenic study on cancer susceptibility. Cancer Res. 2003:63:2440-6.

27. Wang LE, Bondy ML, Shen H, El-Zein R, Aldape K, Cao Y, Pudavalli V, Levin VA, Yung WK, Wei Q. Polymorphisms of DNA repair genes and risk of glioma. Cancer Res. 2004;64(16):5560-3.

28. Hirata H, Hinoda Y, Matsuyama H, Tanaka Y, Okayama N, Suehiro Y, Zhao $H_{\text {, }}$ Urakami S, Kawamato K, Kawakami T, Igawa M, Naito K, Dahiya R. Polymorphisms of DNA repair genes are associated with renal cell carcinoma. Biochem Biophys Res Commun. 2006a;342:1058-62.

29. Zijno A, Verdina A, Galati R, Leopardi P, Marcon F, Andreoli C, Rossi S, Crebelli R. Influence of DNA repair polymorphisms on biomarkers of genotoxic damage in peripheral lymphocytes of healthy subjects. Mutat Res. 2006;600(1-2):184-92.

30. Zhu Y, Yang H, Chen Q, Lin J, Grossman HB, Dinney CP, Wu X, Gu J. Modulation of DNA damage/DNA repair capacity by XPC polymorphisms. DNA Repair. 2008;7:141-8.

31. Veeriah S, Miene C, Habermann N, Hofmann T, Klenow S, Sauer J, Bohmer F, Wolfl S, Pool-Zobel BL. Apple polyphenols modulate expression of selected genes related to toxicological defence and stress response in human colon adenoma cells. Int J Cancer. 2008;122:2647-55.

32. Pfaffle MW. A new mathematical model for relative quantification in real time RT PCR. Nucleic Acid Res. 2001;29:2002-7.

33. Lahiri DK, Nurnberger J. A rapid non-enzymatic method for the preparation of HMW DNA from blood for RFLP studies. Nucleic Acid Res. 1991;19(19): 5444. https://doi.org/10.1093/nar/19.19.5444

34. Karanjawala ZE, Murphy N, Hinton DR, Hsieh CL, Lieber MR. Oxygen metabolism causes chromosome breaks and is associated with the neuronal apoptosis observed in DNA double-strand break repair mutants. Curr Biol. 2002;12(5):397-402.

35. Warren AJ. DNA-repair enzyme turns to translation. Nature. 2020;579(7798): 198-9.

36. Korabiowska M, König F, Schlott T, Slotty P, Romeike B, Cordon-Cardo C, Brinck U. Quantitative analysis of Ku70 and Ku80 mRNA gene expression in melanoma brain metastases. Correlation with immunohistochemistry and in situ hybridization. Cancer Genomics Proteomics. 2004;1:225-30.

37. Gottlieb TM, Jackson SP. The DNA dependent protein kinases: requirement for DNA ends and association with Ku antigen. Cell. 1993;72(1):131-42.

38. Hartley KO, Gell D, Smith GC, Zhang H, Divecha N, Connelly MA, Admon A, Lees-Miller SP, Anderson CW, Jackson SP. DNA-dependent protein kinase catalytic subunit: a relative of phosphatidylinosytol 3-kinase and the ataxia teleangiectasia gene product. Cell. 1995;82:849-56.

39. Kurimasa A, Ouyang H, Dong L, Wang S, Li X, Cordon-Cardo C, Chen DJ, Li GC. Catalytic subunit of DNA dependent protein kinase. Impact on lymphocyte development and tumorigenesis. Proc Nat Acad Sci USA. 1999; 96:1403-8.

40. Amundson SA, Bittner M, Chen Y, Trent J, Meltzer P, Fornace AJ Jr. Fluorescent cDNA microarray hybridization reveals complexity and heterogeneity of cellular genotoxic stress responses. Oncogene. 1999;18: 3666-72.

41. Amundson SA, Bittner M, Fornace AJ Jr. Functional genomics as a window on radiation stress signaling. Oncogene. 2003a;22:5828-33.

42. Amundson SA, Lee RA, Koch-Paiz CA, Bittner ML, Meltzer P, Trent JM, Fornace AJ Jr. Differential responses of stress genes to low dose-rate gamma irradiation. Mol Cancer Res. 2003b;1:445-52.

43. Schmidt-Ullrich RK, Dent P, Grant S, Mikkelsen RB, Valerie K. Signal transduction and cellular radiation responses. Radiat Res. 2000;153:245-57.

44. Kadhim MA, Moore SR, Goodwin EH. Interrelationships amongst radiationinduced genomic instability, bystander effects, and the adaptive response. Mutat Res. 2004:568:21-32.

45. Coleman MA, Yin E, Peterson LE, Nelson D, Sorensen K, Tucker JD, Wyrobek AJ. Low-dose irradiation alters the transcript profiles of human lymphoblastoid cells including genes associated with cytogenetic radioadaptive response. Radiat Res. 2005;164:369-82.

46. Wilson GD. Radiation and cell cycle: revisited. Cancer Metastasis Rev. 2004; 23:209-25.

47. Fachin AL, Mello SS, Sandrin-Garcia P, Junta CM, Donadi EA, Passos Geraldo AS, Sakamoto-Hojo ET. Gene expression profiles in human lymphocytes irradiated in vitro with low doses of gamma rays. Radiat Res. 2007;168(6): 650-65.
48. Jeggo P, Lavin MF. Cellular radio-sensitivity: how much better do we understand it? Int J Radiat Biol. 2009:85(12):1061-81.

49. Fujii Y, Yurkon CR, Maeda J, Genet S, Kubota N, Fujimori A, Mori T, Maruo K, Kato TA. Comparative study of radio-resistance between feline cells and human cells. Radiat Res. 2013;180(1):70-7.

50. Cornetta T, Festa F, Testa A, Cozzi R. DNA damage repair and genetic polymorphisms: assessment of individual sensitivity and repair capacity. Int J Radiation Oncol Biol Physics. 2006;66(2):537-45.

51. Ludwig DL, Chen F, Peterson SR, Nussenzweig A, Li GC, Chen DJ. Ku80 gene expression is Sp1-dependent and sensitive to CpG methylation within a novel cis element. Gene. 1997:199(1-2):181-94.

52. Sipley JD, Menninger JC, Hartley KO, Ward DC, Jackson SP, Anderson CW. Gene for the catalytic subunit of the human DNA-activated protein kinase maps to the site of the XRCC7 gene on chromosome 8. Proc Nat Acad Sci USA. 1995:92:7515-9.

53. Wang SY, Peng L, Li CP, Li AP, Zhou JW, Zhang ZD, Liu QZ. Genetic variants of the XRCC7 gene involved in DNA repair and risk of human bladder cancer. Int J Urol. 2008;15:534-9.

54. Valerie K, Povirk LF. Regulation and mechanisms of mammalian double strand break repair. Oncogene. 2003;22:5792-812.

55. d'Errico A, Malats N, Vineis P, Boffetta P. Review of studies of selected metabolic polymorphisms and Cancer. Int Agency Res Cancer Sci Pub. 1999; 148:323-93

56. Goode EL, Ulrich CM, Potter JD. Polymorphisms in DNA repair genes and associations with cancer risk. Cancer Epidemiol Biomarkers Prev. 2002;11: 1513-30.

57. Gangwar R, Ahirwar D, Mandhani A, Mittal RD. Do DNA repair genes OGG1, XRCC3 and XRCC7 have an impact on susceptibility to bladder cancer in the north Indian population? Mutat Res. 2009;680:56-63.

58. Hirata H, Hinoda Y, Tanaka Y, Okayama N, Suehiro Y, Kawamoto K, Kikuno N, Majid S, Vejdani K, Dahiya R. Polymorphisms of DNA repair genes are risk factors for prostate cancer. Eur J Cancer. 2007:43:231-7.

59. Liu Y, Zhang H, Zhou K, Chen L, Xu Z, Zhong Y, Liu H, Li R, Shugart YY, Wei Q, Jin L, Haung F, Lu D, Zhou L. Tagging SNPs in non-homologous endjoining pathway genes and risk of glioma. Carcinogenesis. 2007;28:1906-13.

60. Mandal RK, Kapoor R, Mittal RD. Polymorphic variants of DNA repair gene XRCC3 and XRCC7 and risk of prostate cancer: a study from north Indian population. DNA Cell Biol. 2010;29:669-74.

\section{Publisher's Note}

Springer Nature remains neutral with regard to jurisdictional claims in published maps and institutional affiliations.
Ready to submit your research? Choose BMC and benefit from:

- fast, convenient online submission

- thorough peer review by experienced researchers in your field

- rapid publication on acceptance

- support for research data, including large and complex data types

- gold Open Access which fosters wider collaboration and increased citations

- maximum visibility for your research: over $100 \mathrm{M}$ website views per year

At $\mathrm{BMC}$, research is always in progress.

Learn more biomedcentral.com/submissions 